Department of Community

Medicine, University

College and Middlesex

School of Medicine,

London]WC1E 6EA

M G Marmot, FFCM, professor

Department of

Epidemiology and

Population Sciences,

London School of Hygiene

and Tropical Medicine,

London WC1E 7HT

George Davey Smith, MB,

lecturer

Correspondence to:

Professor Marmot.

BrMed f 1989;299:1547-51

FIG $1-$ Trends in mortalit among people aged 30-69, 1950-86

\title{
Why are the Japanese living longer?
}

\author{
M GlMarmot, George Davey Smith
}

In Britain could we within two decades improve life expectancy to the point that would be achieved by abolishing heart disease and most cancers? In the past 20 years Japan has achieved improvements in life expectancy of this magnitude. Japanese people now have the longest life expectancy in the world, with people in England and Wales lying a long way behind.

Morishima wrote a book entitled Why has Japan Succeeded?.' Although he was referring to economic success, Japan's economic development and health development are probably closely linked. The same factors may have benefited both, and, in addition, economic development may itself lead to reductions in mortality. We obtained data on the recent fall in mortality in Japan and investigated some of the reasons that might lie behind it. Although the study focused on Japan, it may also contribute to current debates on the degree to which social and health policy influences the British public's health.

\section{British and Japanese life expectancy}

Although it might be thought that we are reaching the biological limits of life expectancy, experiences in Japan suggest otherwise. A Japanese boy born in 1986 could expect to live 75.2 years compared with 71.9 years for a boy born in England or Wales, assuming that mortality remained constant (table I). The life expectancy of a girl born in Japan is now 80.9 years compared with $77 \cdot 7$ years for a girl born in England or

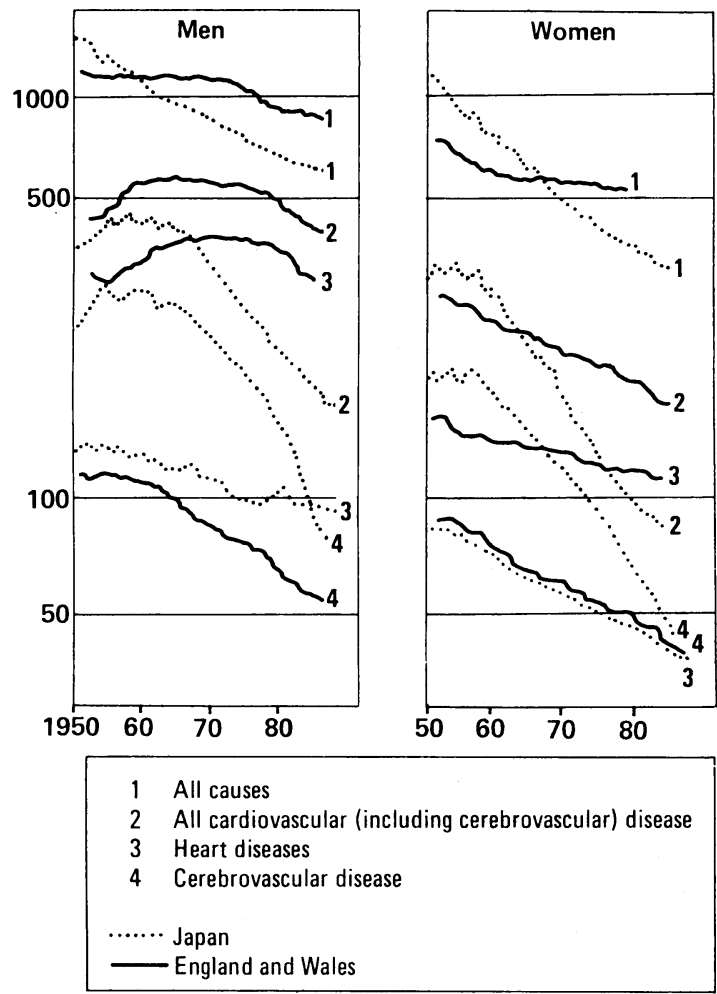

TABLE I-Life expectancy (years) of Fapanese and of English and Welsh populations since 1955

\begin{tabular}{|c|c|c|c|c|}
\hline & \multicolumn{2}{|c|}{ Males } & \multicolumn{2}{|c|}{ Females } \\
\hline & At birth & At age 85 & At birth & At age 65 \\
\hline \multicolumn{5}{|l|}{ Japan': } \\
\hline 1955 & $63 \cdot 6$ & $11 \cdot 8$ & $67 \cdot 8$ & $14 \cdot 1$ \\
\hline 1965 & $67 \cdot 7$ & 11.9 & $72 \cdot 9$ & $14 \cdot 6$ \\
\hline 1975 & $71 \cdot 7$ & 13.7 & $76 \cdot 9$ & $16 \cdot 6$ \\
\hline 1980 & $73 \cdot 4$ & $14 \cdot 6$ & $78 \cdot 8$ & $17 \cdot 7$ \\
\hline 1986 & $75 \cdot 2$ & $15 \cdot 9$ & $80 \cdot 9$ & $19 \cdot 3$ \\
\hline \multicolumn{5}{|c|}{ England and Wales ${ }^{2}$ : } \\
\hline 1955 & $67 \cdot 5$ & $11 \cdot 8$ & $73 \cdot 0$ & $14 \cdot 8$ \\
\hline 1965 & 68.5 & $12 \cdot 1$ & $74 \cdot 7$ & $15 \cdot 8$ \\
\hline 1975 & $69 \cdot 5$ & $12 \cdot 4$ & $75 \cdot 7$ & $16 \cdot 4$ \\
\hline 1980 & $70 \cdot 4$ & $12 \cdot 8$ & $76 \cdot 6$ & $16 \cdot 8$ \\
\hline $1984-86$ & 71.9 & $13 \cdot 4$ & $77 \cdot 7$ & $17 \cdot 3$ \\
\hline
\end{tabular}

Wales. ${ }^{2-4}$ Life expectancy in Japan has increased rapidly: from 1965 to 1986 it rose by $7 \cdot 5$ years for men and 8 years for women. ${ }^{+}$To put these figures in perspective, if heart disease was abolished and other causes of death remained constant life expectancy would increase by only 4.7 years in England and Wales (P Boyle, personal communication).

Life expectancy is heavily influenced by mortality in the first year of life, but table I shows that even at age 65 life expectancy in Japan has improved by $4 \cdot 0$ years for men and 4.7 years for women compared with 1.3 and 1.5 years for men and women in England and Wales over the same period..$^{2+}$

Total mortality among people aged 30-69 was higher in Japan than England and Wales until the 1960s, when it began to fall steeply in Japan (fig 1). ${ }^{5}$ Now the rate is considerably lower in Japan.

\section{Causes of death}

Breast, cervical, and lung cancer, coronary heart disease, and respiratory diseases are more important causes of death in England and Wales than Japan, whereas stroke, stomach cancer, suicide, cirrhosis, and maternal mortality are less important than in Japan. ${ }^{5 .}$ The disease pattern of these countries cannot be correlated with their degree of development or industrialisation. Over the past 25 years, however, the trends in mortality in Japan have been more favourable for virtually all categories of mortality. For example, Japan has had the highest mortality in the world from stroke and one of the lowest from heart diseases, but, as figure 1 shows, both of these have fallen to a greater extent than in England and Wales. Heart disease is more common in Japan than it was; as the mean age of the Japanese population increases the absolute number of cases of heart disease increases. However, the mortality has declined within each age range, and this is reflected in the age adjusted rates in figure 1.

\section{Recent trends in mortality}

Table II shows the age specific trends in mortality for 1980-6. Infant mortality decreased by $33 \%$ in boys 


\begin{tabular}{|c|c|c|c|c|c|c|c|c|}
\hline & \multicolumn{2}{|c|}{ All causes } & \multicolumn{2}{|c|}{ Stroke } & \multicolumn{2}{|c|}{$\begin{array}{c}\text { Ischaemic } \\
\text { heart } \\
\text { disease }\end{array}$} & \multicolumn{2}{|c|}{$\begin{array}{c}\text { Other } \\
\text { heart } \\
\text { disease }\end{array}$} \\
\hline & Male & Female & Male & Female & Male & Female & Male & Female \\
\hline \multicolumn{9}{|l|}{ Mortality: } \\
\hline $1980^{\circ}$ & $8 \cdot 3$ & 6.6 & & & & & & \\
\hline 1986 & $5 \cdot 6$ & $4 \cdot 8$ & & & & & & \\
\hline \multicolumn{9}{|l|}{ Age 45-49‡: } \\
\hline 1980 & 436 & 211 & 68 & 34 & 21 & 6 & 35 & 14 \\
\hline 1986 & 354 & 180 & 42 & 22 & 15 & 4 & 34 & 13 \\
\hline \multicolumn{9}{|l|}{ Age 60-64‡: } \\
\hline 1980 & 1506 & 785 & 275 & 161 & 123 & 45 & 110 & 66 \\
\hline 1986 & 1266 & 621 & 154 & 90 & 82 & 30 & 108 & 56 \\
\hline \multicolumn{9}{|l|}{ Age 75-79キ: } \\
\hline 1980 & 7586 & 4778 & 2063 & 1452 & 604 & 399 & 779 & 556 \\
\hline 1986 & 6122 & 3586 & 1133 & 822 & 469 & 302 & 733 & 521 \\
\hline
\end{tabular}

„ Most of these deaths were caused by "heart failure."

† Expressed per 1000 live births.

$\ddagger$ Expressed per 100000 population

and $27 \%$ in girls. ${ }^{4}$ Over the same period infant mortality in England and Wales decreased by $17 \%$ in boys and $25 \%$ in girls. ${ }^{6}$ The decrease in mortality among people in early middle age and older in Japan was steep: $19 \%$ in men and $15 \%$ in women aged $45-49$, $16 \%$ and $21 \%$ respectively in those aged $60-64$, and $19 \%$ and $25 \%$ in those aged $75-79$. In the oldest age group (75-79) mortality from cerebrovascular disease decreased by an unprecedented $44 \%$ over the six years. ${ }^{+}$The Japanese are more likely to record heart failure on a death certificate than we are in Britain. Even when this is allowed for by combining all categories of heart disease the rate for heart disease is still low and decreasing.

A general explanation for the low mortality in Japan cannot be obtained. There is no single answer, and hypotheses are difficult to test. Nevertheless, mortality is an important public health issue, and by identifying the possible reasons for low mortality in Japan we may be able to produce an agenda for research. The effort to understand the Japanese success in reducing mortality will also increase knowledge of the effects of social organisation, economics, and culture on a population's health. Possible explanations are discussed below.

\section{Medical care}

Several approaches could be taken to assess the effect of medical care on life expectancy and mortality. Firstly, each disease could be examined individually. Both the efficacy of treatments and the extent to which they are applied effectively across the population will affect mortality. For example, treatment of hyperten-

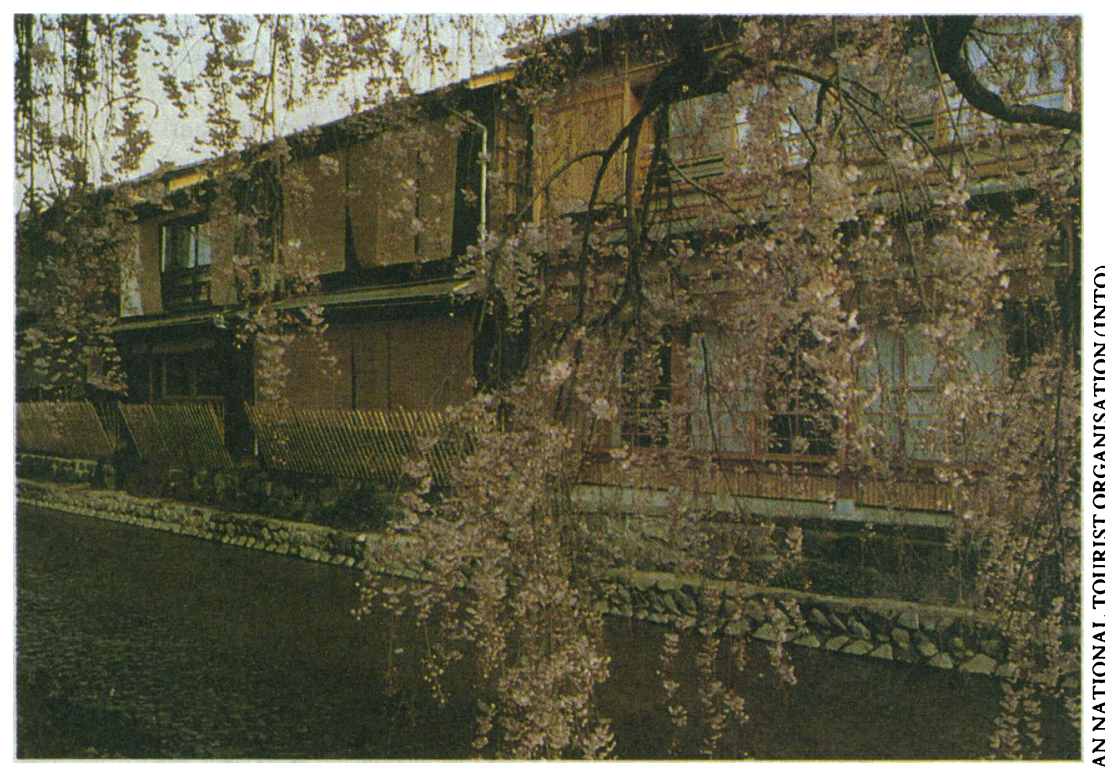

Street in Takayama sion reduces the risk of stroke. If the Japanese had been especially rigorous in detecting and treating patients with hypertension this would have reduced deaths due to stroke. A reduction in mortality of $44 \%$ in six years among people aged 75-79, however, is not a simple therapeutic task. About half of deaths from stroke occur in patients with hypertension (casual diastolic pressure $\geqslant 100 \mathrm{~mm} \mathrm{Hg}$ ). A reduction in the number of deaths from stroke by $44 \%$ due to drug treatment would imply that none of the patients with hypertension were treated in 1980 but they all were in 1986 . It is unlikely that such a dramatic change in treatment policy would have taken place. Furthermore, lowering blood pressure in patients with hypertension does not reduce the risk of stroke to that in those who have always had normal blood pressure. Improved treatment could have contributed to the fall in the incidence of stroke but cannot reasonably be considered to have produced the large decrease in mortality.

A more general approach would be to examine trends in mortality from diseases amenable to medical intervention. Charlton and Velez examined trends in mortality from 1951 to 1980 for a group of conditions that could be prevented by medical intervention. ${ }^{7}$ The countries studied were Japan, England and Wales, the United States, France, Italy, and Sweden. Japan started with by far the highest mortality from these conditions in 1951, largely because stroke was included, and it showed the most dramatic decrease of all the countries studied. Unlike the other countries, however, Japan also showed a steep decline in mortality from other causes. In 1951 Japan had the highest mortality from these other causes but by the late 1960s it had the lowest, and the downward trend continued after that time. It seems that the decrease in mortality in Japan is not solely due to improved medical care.

A third approach would be to look at expenditure on health services. In 1980 Japan spent $6.3 \%$ of its gross domestic product on health care, a similar amount to that spent in the United Kingdom (5.8\%) and substantially less than that spent in North America (9.5\%) and West Germany (8.0\%). ${ }^{8}$ Recently it has been proposed that comparative costs should be taken into account when calculating expenditure (for example, how much staff are paid. $)^{8}$ When parities of purchasing power are used Japan spends more than the United Kingdom but less than Norway and France and about the same as Austria, West Germany, North America, and The Netherlands. The countries with high expenditure on health care all have shorter life expectancies than Japan. Similarly, Japan has relatively low rates of doctors and nurses to the population: one per 740 and one per 210 respectively in 1981 , compared with one per 680 and one per 120 for the United Kingdom in the same year. ${ }^{9}$ Since 1965 these ratios have not increased any faster in Japan than in the United Kingdom.

\section{Public health services}

How much do organised public health services affect the health of the public? Health centres were established in Japan after the second world war, and in 1980 there were 855 , which were funded both nationally and locally. The centres ran a programme to control tuberculosis, and they continue to have responsibility for controlling communicable diseases, including by vaccination. The emphasis of their work has changed to include environmental problems, cardiovascular disease, cancer, maternal and child health, mental health, rehabilitation, and care of the elderly (H Nakagawa, personal communication).

Widespread screening for cardiovascular disease and cancer was introduced in 1983. For people who do not have a regular check up at work the local health authority will provide one either directly or by con- 


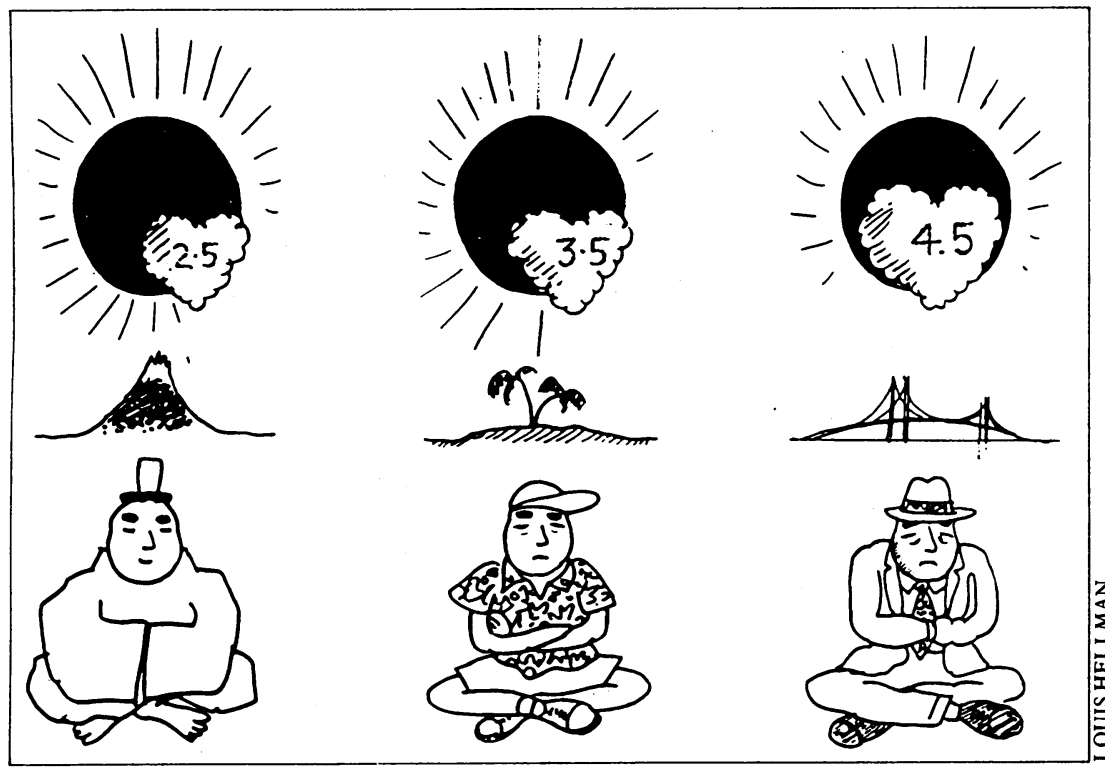

FIG 2-Prevalence (percentage) of coronary heart disease (as indicated by $Q$ waves in electrocardiogram) among men of Fapanese ancestry living in Fapan (left), Honolulu (centre), and San Francisco Bay area (right) ${ }^{10}$

tracting local doctors. Health checks are followed by individual counselling and health education. It will be important to determine whether this makes a further contribution to the reduction in mortality.

\section{Genetic differences}

The long life expectancy in Japan is unlikely to be due simply to the fact that the Japanese have some intrinsic biological advantage. A genetic explanation would not account for the dramatic improvement in life expectancy over the past 20 years. It also would not account for the changes in mortality patterns that have occurred among Japanese migrants to the United States of America. Among men of Japanese ancestry living in Japan, Honolulu, and San Francisco Bay area the prevalence of coronary heart disease is $2 \cdot 5 \%, 3 \cdot 5 \%$, and $4.5 \%$ respectively (fig 2 ). ${ }^{10}$ These changes must be due to differences in environment or lifestyle.

\section{Nutrition}

The Japanese are concerned that their diet is becoming Westernised. People visiting Japan from the West find it difficult to eat their normal high fat diet (table III)." Even among the "Westernised" inhabitants of the huge city of Osaka dietary fat contributed only $23 \%$ of energy intake compared with $42 \%$ in Britain. The ratio of polyunsaturated to saturated fat was $1 \cdot 1$ compared with 0.34 in Britain. Although the diet has changed from the rural diet (for example, that of the population of Akita), where fat contributed $11 \%$ of energy and the ratio of polyunsaturated to saturated fat was $1 \cdot 2$, it still has a much lower fat content than the Western diet. Diet is probably an important factor in the low rate of coronary heart disease in Japan and may also contribute to the low rate of cancer of the colon and breast.

The other striking feature of the Japanese diet is the extremely high salt intake, which many Japanese experts consider responsible for the high incidence of strokes. Certainly, there is a geographic correlation between mortality from stroke and dietary salt consumption. Consumption of salt has decreased in recent years in Japan, from $13.7 \mathrm{~g}$ a day in 1976 to $12.4 \mathrm{~g}$ in 1983. ${ }^{12}$ This can probably be attributed to an explicit public health campaign to reduce salt intake. In addition, the manufacturers of miso soup (a daily feature of the traditional Japanese diet) reduced the salt content of their product. Joossens has argued that this change to a diet containing less salt and fewer preserved foods is responsible for the decrease in both stroke and stomach cancer. ${ }^{13}$

\section{Social and economic forces}

There is a sharp contrast between Japan's economic performance and that of Britain during 1965-86, when Japan's life expectancy increased dramatically (table IV). Japan's low inflation, high growth rate, and low unemployment are in sharp contrast to Britain's performance, which is worse than the average for countries in the Organisation for Economic Cooperation and Development. ${ }^{1+15}$ Japan's gross national product was lower than the United Kingdom's in the 1970 s but considerably higher in the 1980s. In terms of gross national product per person Japan ranked fourth in 1987 after Switzerland, North America, and Norway, whereas the United Kingdom was 15 th. The figures for gross national product give little information on how that income is distributed. Wilkinson argues that there is a relation between income and life expectancy but that it is stronger with measures of income distribution than with gross national products. ${ }^{16}$ Table $\mathrm{V}$ shows two measures of income

TABLE III - Daily nutrient intake of four groups of fapanese men aged 40-59 based on 24 hour dietary recall, 1975-7'

\begin{tabular}{|c|c|c|c|c|}
\hline Nutrient & $\begin{array}{c}\text { Clerical } \\
\text { workers, } \\
\text { Osaka } \\
(n=114)\end{array}$ & $\begin{array}{c}\text { Manual } \\
\text { workers, } \\
\text { Osaka } \\
(\mathrm{n}=117)\end{array}$ & $\begin{array}{c}\text { Inhabi- } \\
\text { tants, } \\
\text { Kochi } \\
(\mathbf{n}=157)\end{array}$ & $\begin{array}{c}\text { Inhabi- } \\
\text { tants, } \\
\text { Akita A } \\
(n=174)\end{array}$ \\
\hline $\begin{array}{l}\text { Energy }(M J) \\
\text { Polyunsaturated: }\end{array}$ & 853 & 915 & 1049 & 997 \\
\hline saturated fat & $1 \cdot 1$ & $1 \cdot 2$ & $1 \cdot 4$ & $1 \cdot 2$ \\
\hline Cholesterol (mg) & 487 & 432 & 355 & 400 \\
\hline Protein ( $\%$ of total energy) & $14 \cdot 3$ & $13 \cdot 4$ & $14 \cdot 1$ & $14 \cdot 5$ \\
\hline Fat (\% of total energy) & $22 \cdot 9$ & $19 \cdot 3$ & $11 \cdot 0$ & $14 \cdot 4$ \\
\hline $\begin{array}{l}\text { Polyunsaturated fatty acid } \\
\text { (\% of total energy) }\end{array}$ & $6 \cdot 2$ & $5 \cdot 5$ & 3.5 & $4 \cdot 0$ \\
\hline Saturated fatty acid & & & & \\
\hline $\begin{array}{l}\text { (\% of total energy) } \\
\text { Carbohydrate } \% \text { of }\end{array}$ & 5.9 & $4 \cdot 7$ & $2 \cdot 5$ & $3 \cdot 3$ \\
\hline $\begin{array}{l}\text { Carbohydrate (\% of } \\
\text { total energy) }\end{array}$ & $52 \cdot 7$ & $58 \cdot 4$ & 64.9 & $56 \cdot 1$ \\
\hline $\begin{array}{l}\text { Alcohol (\% of } \\
\text { total energy) }\end{array}$ & $11 \cdot 3$ & $9 \cdot 6$ & $10 \cdot 6$ & $16 \cdot 6$ \\
\hline
\end{tabular}

TABLE IV-Economic and social indicators for fapan, and United Kingdom compared with Organisation for Economic Cooperation and Development average

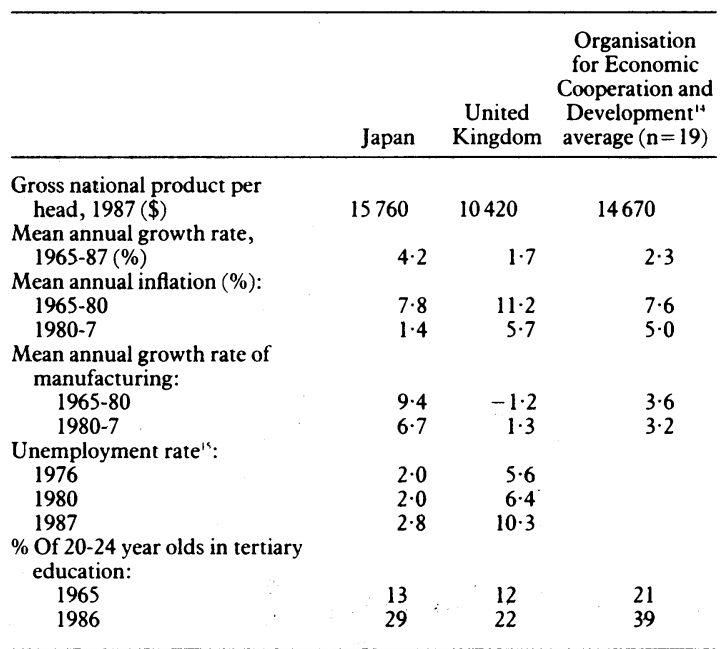

TABLE V-Distribution of total household income (percentage) by centile groups of households

\begin{tabular}{lcc}
\hline & Lowest fifth & Highest fifth \\
\hline United Kingdom, 1979'4 & $7 \cdot 0$ & $39 \cdot 7$ \\
Japan 1979'4 & $8 \cdot 7$ & $37 \cdot 5$ \\
Great Britain, 1976" & $7 \cdot 0$ & $38 \cdot 1$ \\
Great Britain, 1986" & $5 \cdot 9$ & $42 \cdot 2$
\end{tabular}


inequality compiled by the World Bank. In 1979 the lowest earning fifth of households in Japan had a higher share of total household income than those in the United Kingdom $(8 \cdot 7 \% v 7 \cdot 0 \%)$. In 1979 Japan's figure for the lowest earning fifth was the highest of any country reporting to the World Bank. ${ }^{2}$ Similarly, the $37.5 \%$ of the total enjoyed by Japan's top fifth of households was bettered (in the sense of less inequality) only by Belgium (36.0\%) and The Netherlands $(36 \cdot 2 \%)$. Table $\mathrm{V}$ also shows that inequalities in income are increasing in the United Kingdom. ${ }^{15}$

On the basis of these figures for Japan income inequality does not seem to be a necessary ingredient of economic success. If it is related to differences in mortality Britain is heading in the wrong direction, and this may also explain why Japan's life expectancy has overtaken Britain's. Kagamimori and colleagues have examined mortality in occupational groups in Japan in 1970 and 1980 and in England and Wales in 1970-2 and 1979-83 (S Kagamimori, personal communication). They found that the only two occupational groups in Japan that had shorter survival rates than the corresponding rates in England and Wales were miners and farmers. These make up $0.2 \%$ and $9.2 \%$ of the workforce in Japan respectively. The Japanese seemed to have a similar social class gradient in survival to that in England and Wales. Every occupational group in Japan except for the miners showed an improvement in mortality between 1970 and 1980 . This improvement was greatest among blue collar workers, whereas in England and Wales the smallest improvement has occurred among these workers. ${ }^{17}$

Class, defined on the basis of occupation, seems to have an influence on mortality in Japan as it does in Britain but Japanese workers have a longer life expectancy than British workers. This may be related to the fact that material rewards for work seem to be less unevenly distributed in Japan or to the actual nature of work in the two societies.

\section{Work}

Evidence of Japan's economic miracle is beginning to intrude on the beautiful countryside. Now, a typical rural vista is a rice field framed by a factory chimney. This supports the contention that industrial growth has proceeded with little regard for environmental concerns. Much of what we know of cadmium and mercury poisoning in the environment comes from Japan. Thus it is not obvious that "green" concerns are protecting the Japanese worker.

The effects of work on health are not confined to physical hazards. Increasingly it is being recognised that psychosocial work environments, autonomy, a sense of control, earnings, and psychological factors may be important in generating social class differences in health. ${ }^{18-20}$ Japanese workers work long and hard. Figures from one Japanese company showing that their workers took about half of their legal entitlement to annual leave seem strange in Britain. The Japanese workers' commitment to their workplace, and the large companies' lifelong commitment to their workers, are now considered unremarkable. ${ }^{21}$ Although only a fifth of Japanese workers enjoy the guarantee of lifetime employment, ${ }^{22}$ employment in Japan is probably more secure than that in Britain. As increased use of casual labour may contribute to the widening social class inequalities in mortality in the United Kingdom ${ }^{23}$ this is an important topic for future research.

Modern production line processes imply boring, repetitive tasks, and work of this nature has been linked to increased rates of cardiovascular disease. ${ }^{24}$ Manufacturing output per employee has grown by a factor of two in Britain since 1970 and 2.5 in Japan. ${ }^{14}$ One striking difference between the two countries is that in Britain this growth has been accompanied by a massive decline in total manufacturing output (table IV); presumably mean efficiency has improved, partly because less efficient companies have gone out of business. By contrast in Japan there has been no decrease in either output or employment in the manufacturing sector. A greater development of automation in Japan may actually have replaced unskilled repetitive tasks with jobs requiring the skills necessary to manage robots and other complex machines.

Working conditions and participation in the labour force are rarely the same for men and women. If women show the same mortality trends as men it means either that in the Japanese case improvements have affected both sexes similarly or that factors outside work are more important.

\section{Culture and social relationships}

The Japanese will tell the Western observer that everything in Japan is rapidly changing and becoming Westernised. Interestingly, this observation has been constant over time. When the feudal Tokugawa régime became firmly established in the seventeenth century there was concern that contacts with Dutch traders would irrevocably change Japan. In the mid-nineteenth century, during the restoration of the emperor Meiji, when American warships steamed into Japanese waters, there was widespread concern at Westernisation. ${ }^{\prime}$ The novelist Tanizaki, writing about the 1920 s, vividly portrays the Japanese enchantment with Western ideas. ${ }^{25}$ Ishiguro, writing about the postwar period, also conveys the concern that the traditional Japanese way was seen to be going for good. ${ }^{26}$

What strikes the Western observer is not the similarity between Japan and the West but the differences. Baseball and "fast food" notwithstanding, the way people relate to each other and to organisations is very different in Japan. The loyalty and commitment

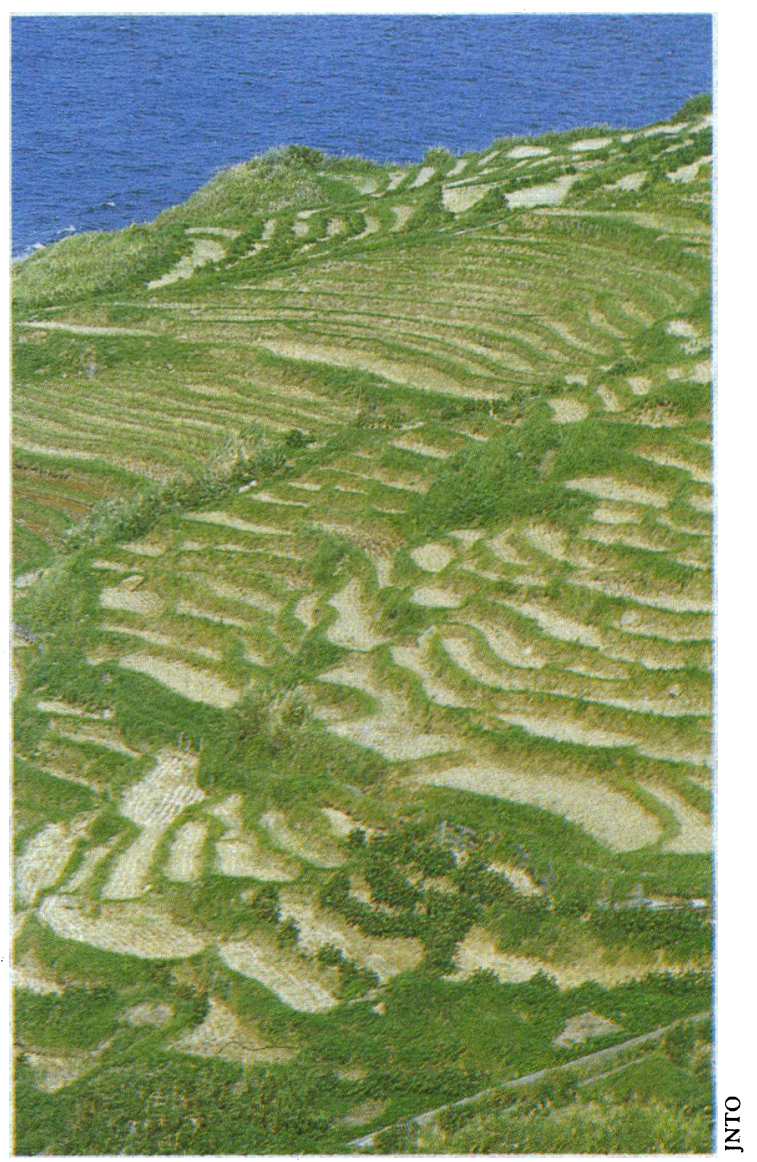

Noto peninsular 


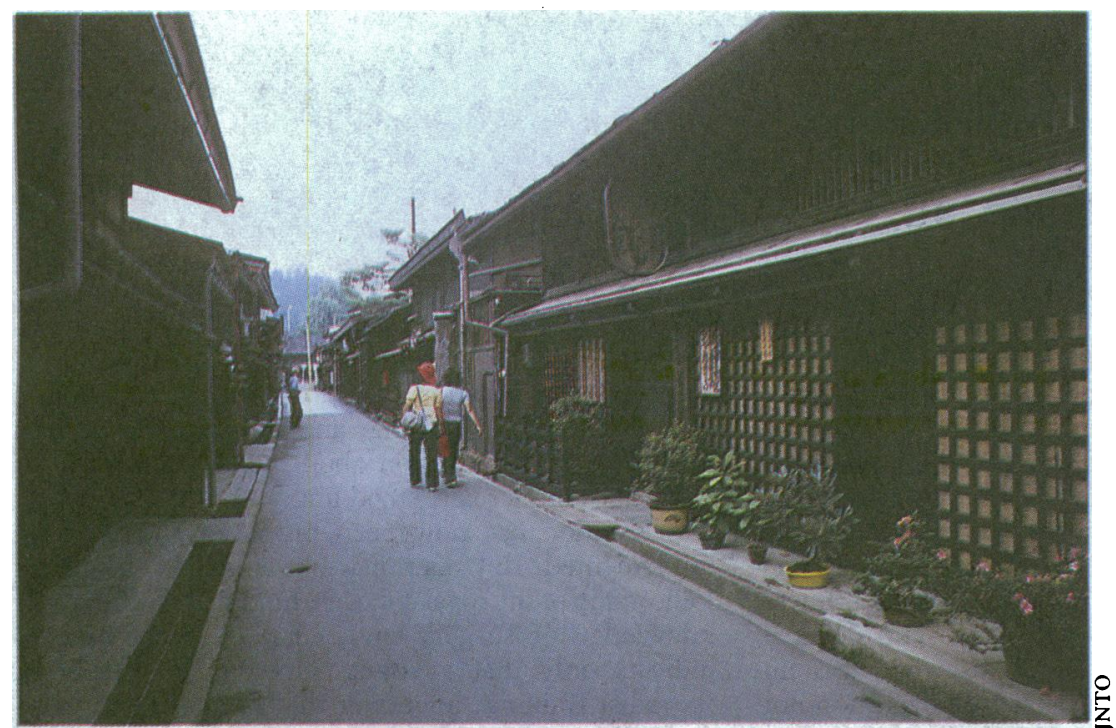

Shirikawa, Kyoto

to the group, the family, and the organisation and the sense of duty to one's superiors in age or status are particularly noticeable. Many of the superficial trappings of status are dispensed with in industry; the managers wear the same spotless white overalls as the men and there is no executive dining room, although there is never any doubt about who is in charge, who should be deferred to, or who is earning the most. Matsumoto suggested that this clear sense of the appropriate order of things and commitment to the group together with the Japanese practice of socialising with coworkers reduce stress. ${ }^{27}$ There is some empirical evidence that this might account for the low rate of coronary heart disease in Japan and the increased rate of the disease among men of Japanese ancestry living in the United States. ${ }^{28}$

Even if Japanese culture does have special features that help keep the Japanese healthy it cannot answer our present question of why Japanese life expectancy has improved so much over a scant 20 years. Though the Japanese are culturally different from the British, they are unlikely to have become more so in the past 20 years.

\section{Conclusions}

Different aspects of the Japanese lifestyle can be used to support or refute different hypotheses. Those wishing to defend Britain's comparatively small expenditure on health care can show that the Japanese improvements have been made despite an equally low expenditure. It is not obvious that Japan's welfare system provides more support than Britain's but its public health system seems to function well; further analysis is needed to determine whether the public health system has influenced the improvements in health. The long life expectancy $(80.9$ years) for women is difficult to reconcile with the unliberated state of Japanese women and a high (though improving) maternal mortality.

In view of the long hours worked by Japanese men our speculation that the organisation of work in Japan may contribute to longer life expectancy will evoke mixed feelings in people looking forward to the postindustrial society and the age of leisure. We cannot comment on whether the Japanese workers are any "happier" than their British counterparts. The worker's commitment to the workplace and the management's commitments to the worker, however, seem stronger than in Britain. If commitment is related to job satisfaction and lack of alienation it may be important for health.

The Japanese diet seems to play an important part in their health. It may make a major contribution towards the low rates of coronary heart disease and cancer of the breast and colon. Persuading the population to reduce its salt intake may have reduced the mortality from stroke and stomach cancer. Smoking has not been considered above. Since 1965 the proportion of Japanese men who smoke has been over $66 \%$, though the rate is now falling slowly. ${ }^{29}$ There was a large and rapid increase in the proportion of people who smoked before 1965, and this may become reflected in an increased incidence of lung cancer, although the incidence is relatively low at present..$^{\text {sa }}$

The success of the Japanese economy must be considered a factor in the rapid improvement in life expectancy. If prosperity is related to health or, more importantly, if relative poverty is related to poor health this may be one way in which Britain could act to improve life expectancy. The Japanese growth in wealth seems to have been accompanied by a narrowing in the differences in income between the richest and poorest. The difference between the richest and poorest in Britain has widened over the past 20 years. This may have profound importance for health.

MGM's visit to Japan was supported by a fellowship from the Royal Society. We thank Sir Cyril Clarke, formerly director of the research unit at the Royal College of Physicians, for the stimulus he gave to this study, and numerous Japanese colleagues, in particular Professor H Ueshima, Dr T Omae, Professor S Kagamimori, and Dr H Nakagawa, for their help.

1 Morishima M. Why has fapan "succeeded"? Cambridge: Cambridge University Press, 1982.

2 Office of Health Economics. Compendium of health statistics. 6th ed. London: OHE, 1987.

3 Office of Population Censuses and Surveys. Mortality statistics 1986. London: HMSO, 1989. (Series DH2.)

4 Statistics and Information Department, Minister's Secretariat, Ministry of Health and Welfare. Vital statistics 1965-1986. Tokyo: Kosei Tokei Kyokai, 1967-88. (In Japanese.)

5 Uemura K, Pisa Z. Trends in cardiovascular disease mortality in industrialised countries since 1950. World Health Stat $Q$ 1988;41:155-78.

5a United Nations. Demographic yearbook 1965-1986. New York: UN, 1967-88.

6 Office of Population Censuses and Surveys. Population Trends 51. London: HMSO, 1988 .

7 Charlton JRH, Velez R. Some international comparisons of mortality amenable to medical intervention. $\mathrm{Br}$ Med f 1986;292:295-301.

8 Parkin W, McGuire AJ, Yule BF. What do international comparisons of health care expenditure really show? Community Med 1989;11:116-23.

9 World Bank. World development report 1988. New York: Oxford University Press, 1988.

10 Marmot MG, Syme SL, Kagan A, et al. Epidemiologic studies of coronary heart disease and stroke in Japanese men living in Japan, Hawaii and heart disease and stroke in Japanese men living in Japan, Hawail and California: prevalence of coronary and hypertensive

11 Ueshima $H$, Lida $M$, Shimamoto $T$, et al. Dietary intake and serum total cholesterol level: their relationship to different lifestyles in several Japanese populations. Circulation 1982;66:519-26.

12 Nutrition Section, Ministry of Health and Welfare. National nutrition survey. Tokyo: Daiichi Shuppan Publishers, 1985. (In Japanese.)

3 Joossens JV. Stroke, stomach cancer and salt: a possible clue to the prevention of hypertension. In: Kesteloot H, Joossens JV, eds. Epidemiology of arterial blood pressure. The Hague: Martinus Nijhoff, 1980:489-508.

14 World Bank. World development report 1989. New York: Oxford University Press, 1989.

15 Central Statistical Office. Social trends 1989. London: HMSO, 1989.

16 Wilkinson RG. Class mortality differentials, income distribution and trends in poverty 1921-1981. Fournal of Social Policy 1989;18:307-35.

7 Marmot MG, McDowall ME. Mortality decline and widening social inequalities. Lancet 1986;i:897-900.

18 Karasek RA. Job demands, job decision latitude and mental strain: implications for job redesign. Administrative Science Quarterly 1979;24:285-308.

19 Wilkinson RG. Income and mortality. In: Wilkinson RG, ed. Class and health: research and longitudinal data. London: Tavistock, 1986:88-114.

$20 \mathrm{Marmot} \mathrm{MG}$, Theorell T. Social class and cardiovascular disease: the Marmot MG, Theorell T. Social class and cardiovascil
contribution of work. Int $\mathcal{f}$ Health Serv 1989;18:659-74

21 Chie N. Fapanese society. California: University of California Press, 1970.

22 van Wolferen K, The enigma of fapanese power. New York: Knopf, 1989:68.

23 Bartley M. Unemployment and health: selection or causation - a false antithesis? Social Health and Illness 1987;10:41-67.

24 Alfredsson L, Spetz CL, Theorell T. Type of occupation, near future hospitalisation for myocardial infarction and some other diagnoses. Int $\mathcal{f}$ Epidemiol 1985;14:378-88.

25 Tanizaki J. Naomi. London: Pan, 1987.

26 Ishiguro K. Artist of the floating world. London: Faber and Faber, 1986.

27 Matsumoto YS. Social stress and coronary heart disease in Japan: a hypothesis. Milbank Memorial Fund Quarterly: Health and Society 1970;48:9-36.

28 Marmot MG, Syme SL. Acculturation and coronary heart disease in JapaneseAmericans. Am J Epidemiol 1976;104:225-47.

29 Ueshima H, Tatara K, Asakura S. Declining mortality from ischemic heart disease and changes in coronary risk factors in Japan, 1956-1980. Am $\mathcal{F}$ Epidemiol 1987;125:62-72.

(Accepted 2 November 1989) 